\section{Leaf Age Affects Gas Exchange in Okra}

\author{
W.F. Whitehead ${ }^{1}$ and B.P. Singh ${ }^{2}$ \\ Agricultural Research Station, Fort Valley State College, Fort Valley, \\ GA 31030-3298
}

Additional index words. Abelmoschus esculentus, transpiration, $\mathrm{CO}_{2}$ exchange rate, stomatal conductance, internal leaf $\mathrm{CO}_{2}$ concentration

\begin{abstract}
Two studies were conducted to assess the effects of leaf aging on gas exchange in okra [Abelmoschus esculentus (L.) Moench] leaves. Gas exchange was measured at 6- to 10day intervals starting 15 days after leaf emergence (DFE) and continuing until senescence at 50 DFE. Rates of transpiration $(E)$, stomatal conductance $\left(g_{s}\right)$ and $\mathrm{CO}_{2}$ exchange $(\mathrm{CER})$ increased as leaves matured up to $\approx 25 \mathrm{DFE}$, about full leaf expansion. Transpiration rate, $\mathrm{g}_{\mathrm{s}}$, and CER declined after $25 \mathrm{DFE}$ and as leaves aged further. Internal leaf $\mathrm{CO}_{2}$ concentration $\left(C_{i}\right)$ was higher in old than young leaves. This study suggests that the most efficient okra canopy would maximize exposure of 25-day-old leaves to sunlight.
\end{abstract}

Okra is a herbaceous, annual, vegetable crop native to the South African and Asian tropics (Thakur, 1989; Thompson and Kelly, 1957). It is particularly popular in the southern United States as a home-garden vegetable and a roadside or farmer's market commodity (Singh, 1987). Research on okra production in the United States has been confined to a few management studies (Albregts and Howard, 1976; Singh, 1987). There is a significant void in information concerning the crop's physiology.

The biological and economic yield of a crop is associated closely with the rate of net $\mathrm{CO}_{2}$ exchange per unit leaf area (CER) (Hobbs and Mahon, 1982; Zelitch, 1982). Factors, such as genotype, assimilate demand by sinks, environment, and leaf age, affect CER (Dwyer et al., 1989; Rasparuva and Rasoluv, 1989). Leaves generally reach the maximum CER at maturity and decline thereafter to senescence (Bhagsari, 1988; Dwyer et al., 1989; Osman and Milthorpe, 1971; Pettigrew and Meredith, 1994). In cotton (Gossypium hirsutum L.), a crop closely related to okra, gas exchange efficiency increases as the newly formed leaves expand. Once the leaves are fully expanded [20 days from emergence (DFE)], however, gas exchange activities begin to decline (Constable and Rawson, 1980; Krieg, 1981; Wullschleger and Oosterhuis, 1989, 1990). Okra, having an indeterminate growth habit, continues to produce new leaves from the main stem and on axillary branches until late in the growing season. A knowledge of the stage of growth at which leaves are most

Received for publication 3 Jan. 1995. Accepted for publication 8 May 1995. Research conducted at Fort Valley Agricultural Research Station, Fort Valley, $\mathrm{Ga}$. Use of trade names does not imply endorsement of the products named nor criticism of similar ones not named. The cost of publishing this paper was defrayed in part by the payment of page charges. Under postal regulations, this paper therefore must be hereby marked advertisement solely to indicate this fact.

${ }^{1}$ Research Associate.

${ }^{2}$ Professor.

HortScience, Vol. 30(5), August 1995 treatments. Recommended cultural practices were followed (Colditz et al., 1984). Fields were irrigated as needed.

One plant within each plot was selected at random and tagged. Located near the uppermost position of the main stem, a newly emerged leaf ( 1 to 2 days old) was labeled on 3 July for Expt. 1 and 10 July for Expt. 2. Gas exchange measurements were initiated $15 \mathrm{DFE}$, when leaf size was large enough $\left(\geq 6.25 \mathrm{~cm}^{2}\right)$ to cover the leaf chamber. Data were collected six times at 6- to 10-day intervals, until senescence. Pods were harvested at an appropriate size.

Gas exchange rates were recorded using a portable steady-state gas-exchange system (ADC model, LAC-2) consisting of a $16-\mathrm{cm}^{3}$ leaf chamber and an infrared gas analyzer (Analytical Development, Huddleston, U.K.). To minimize fluctuations of $\mathrm{CO}_{2}$ found in the plant canopies, ambient air was drawn from outside of the field through a sampling tube, $0.5 \mathrm{~cm}$ in diameter and $6 \mathrm{~m}$ long, provided with a fiberglass filter at its intake. The instrument provided data on photosynthetically active radiation (PAR, $\mu \mathrm{mol} \cdot \mathrm{m}^{-2} \cdot \mathrm{s}^{-1}$ ), transpiration rate $\left(\mathrm{E}, \mathrm{mmol} \cdot \mathrm{m}^{-2} \cdot \mathrm{s}^{-1}\right)$, stomatal conductance $\left(\mathrm{g}_{\mathrm{s}}, \mathrm{mmol} \cdot \mathrm{m}^{-2} \cdot \mathrm{s}^{-1}\right), \mathrm{CO}_{2}$ exchange rate (CER, $\left.\mu \mathrm{mol} \cdot \mathrm{m}^{-2} \cdot \mathrm{s}^{-1}\right)$, and internal leaf $\mathrm{CO}_{2}$ concentration $\left(\mathrm{C}_{\mathrm{i}}, \mu\right.$ liters.liter $\left.{ }^{-1}\right)$. The readings were taken between 1000 and $1300 \mathrm{HR}$ with the PAR at the leaf surface exceeding $1200 \mu \mathrm{mol} \cdot \mathrm{m}^{-2} \cdot \mathrm{s}^{-1}$. The ambient temperature ranged from 33 to 37C in Expt. 1 and from 29 to 37C in Expt. 2.

All data were subjected to analyses of variance (SAS Institute, Cary, N.C). Regression analyses were conducted to assess the relationship of gas exchange rates and leaf aging.

\section{Results and Discussion}

On average, 25 days elapsed between the day of leaf emergence and full leaf blade expansion. Apparent senescence (yellowing of leaves) began $\approx 40 \mathrm{DFE}$, and by $50 \mathrm{DFE}$, leaves were $>50 \%$ yellow.

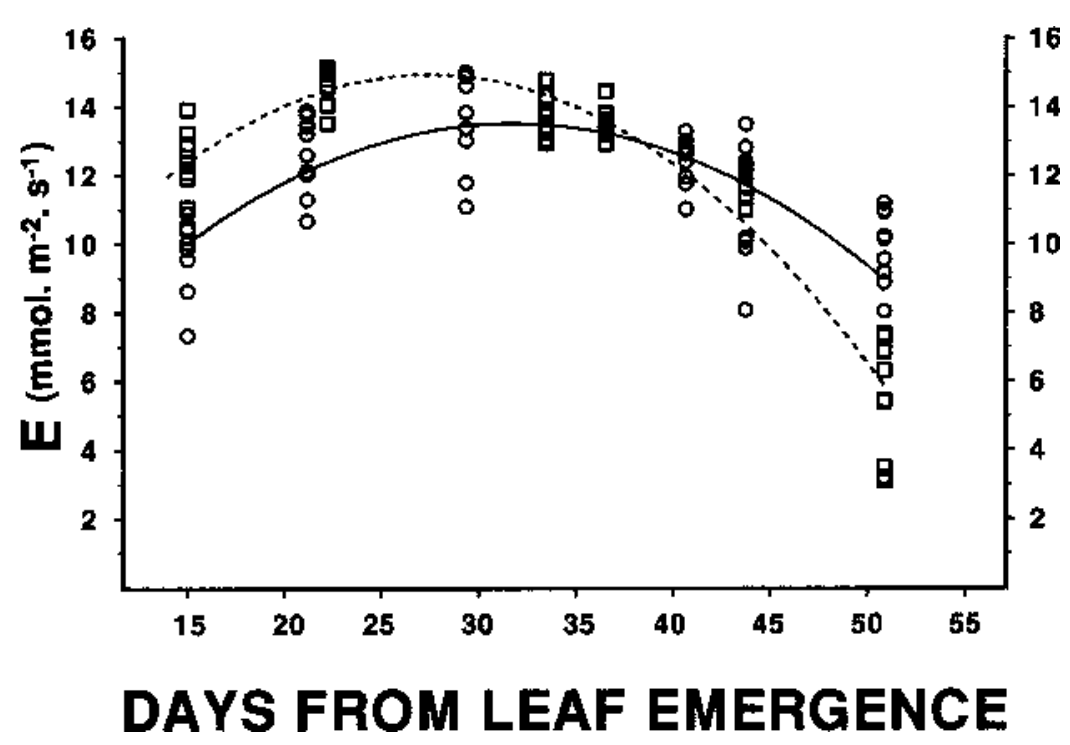

Fig. 1. Effects of leaf age on transpiration rate (E) of okra. (—O- Expt. 1, y $=9.581+0.4528 \mathrm{x}-0.01307 \mathrm{x}^{2}$, $r^{2}=0.52^{* *} ;(------)$ Expt. $2, \mathrm{y}=11.94+0.4549 \mathrm{x}-0.01732 \mathrm{x}^{2}, r^{2}=0.89^{* *}$. ${ }^{* *}$ Significant at $P \leq 0.01$. 
Leaf age had a significant effect on $\mathrm{E}, \mathrm{g}_{\mathrm{s}}$, $\mathrm{CER}$, and $\mathrm{C}_{\mathrm{i}}$. A quadratic equation provided the best fit for the relationship between leaf age and E (Fig. 1) in both experiments. Transpiration rate increased up to 25 to $30 \mathrm{DFE}$ and declined as the leaf aged further. The maximum E rates for Expt. 1 and Expt. 2 were 13.5 and $14.7 \mathrm{mmol} \cdot \mathrm{m}^{-2} \cdot \mathrm{s}^{-1}$, respectively. Regression of $g_{s}$ on leaf age was cubic in Expt. 1 and quadratic in Expt. 2 (Fig. 2). The $g_{s}$ value in both experiments peaked at $\approx 25$ DFE. The relationship of CER with the age of the leaf was cubic in Expt. 1 and quadratic in Expt. 2 (Fig. 3). During the leaf expansion period, increase in CER/day amounted to 1 $\mu \mathrm{mol} \cdot \mathrm{m}^{-2} \cdot \mathrm{s}^{-1}$. The CER declined after full expansion with aging by an average daily rate of $0.22 \mu \mathrm{mol} \cdot \mathrm{m}^{-2} \cdot \mathrm{s}^{-1}$. The relationship of $\mathrm{C}_{\mathrm{i}}$ and leaf age was quadratic for both experiments (Fig. 4). The $\mathrm{C}_{\mathrm{i}}$ content declined during leaf expansion. Once the leaf was fully expanded, $\mathrm{C}_{\mathrm{i}}$ increased with age.

According to our results, water vapor and $\mathrm{CO}_{2}$ exchange were affected similarly by leaf aging. Since the water vapor and $\mathrm{CO}_{2}$ exchanges take place through the same leaf pores, similar behavior would be expected. Similar results have been obtained with other crops (Beardsell et al., 1973; Frank, 1981). An increase in water vapor and $\mathrm{CO}_{2}$ exchange rate during leaf expansion may be attributable to a high level of activity in the mesophyll tissue of young leaves and wide stomatal opening (DeMichele and Sharpe, 1972). The increase in $\mathrm{C}_{\mathrm{i}}$ of the aging leaves may have resulted from slower $\mathrm{CO}_{2}$ fixation and smaller stomatal opening. The study suggests that an ideal okra canopy should be such that 25-day-old leaves are exposed to the maximum amount of sunlight.

\section{Literature Cited}

Albregts, E.E. and C.M. Howard. 1976. Response of four okra cultivars on mulched beds to plant density. HortScience 11:242.

Beardsell, M.F., K.J. Mitchell, and R.G. Thomas. 1973. Transpiration and photosynthesis in soybean. J. Expt. Bot. 24:587-595.

Bhagsari, A.S. 1988. Photosynthesis and stomatal conductance of selected root crops as related to leaf age. Crop Sci. 28:902-906.

Colditz, P., J.M. Barber, and D. Granberry. 1984. Okra. Univ. of Georgia, College of Agr. Coop. Ext. Serv. Circ. 627.

Constable, G.A. and H.W. Rawson. 1980. Effect of leaf position, expansion and age on photosynthesis, transpiration and water use efficiency of cotton. Austral. J. Plant Physiol. 7:89-100.

DeMichele, D.W. and P.J.H. Sharpe. 1972. A morphological and physiological model of the stomata, p. 69-85. In: C. Murphy, J.D. Hesketh, and B.R. Strain (eds.). Workshop on tree growth dynamics and modeling, 12 Oct. 1971, Durham, N.C.

Dwyer, L.M., D.W. Stewart, D. Balchin, L. Houwring, C.J. Marur, and R.I. Hamilton. 1989. Photosynthetic rates of six maize cultivars during development. Agron. J. 81:597-602.

Frank, A.B. 1981. Effect of leaf age and position on photosynthesis and stomatal conductance of forage grasses. Agron. J. 73:70-74.

Hobbs, S.L.A. and J.D. Mahon. 1982. Variation, heritability and relationship to yield of physi-

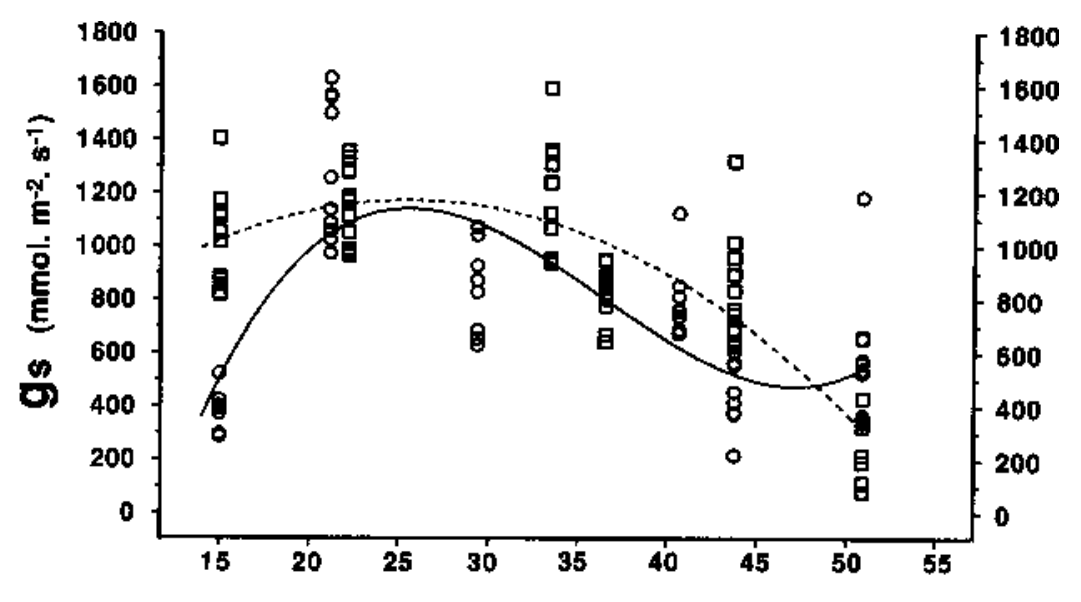

\section{DAYS FROM LEAF EMERGENCE}

Fig. 2. Effects of leaf age on rate of stomatal conductance $\left(\mathrm{g}_{\mathrm{s}}\right)$ of okra. $(-\bigcirc-)$ Expt. $1, \mathrm{y}=356.9+157.2 \mathrm{x}$ $-9.372 \mathrm{x}^{2}+0.1431 \mathrm{x}^{3}, r^{2}=0.50^{* *} ;(---\square--)$ Expt. $2, \mathrm{y}=992.5+31.96 \mathrm{x}-1.408 \mathrm{x}^{2}, r^{2}=0.66^{* *}$. ${ }^{* *}$ Significant at $P \leq 0.01$.

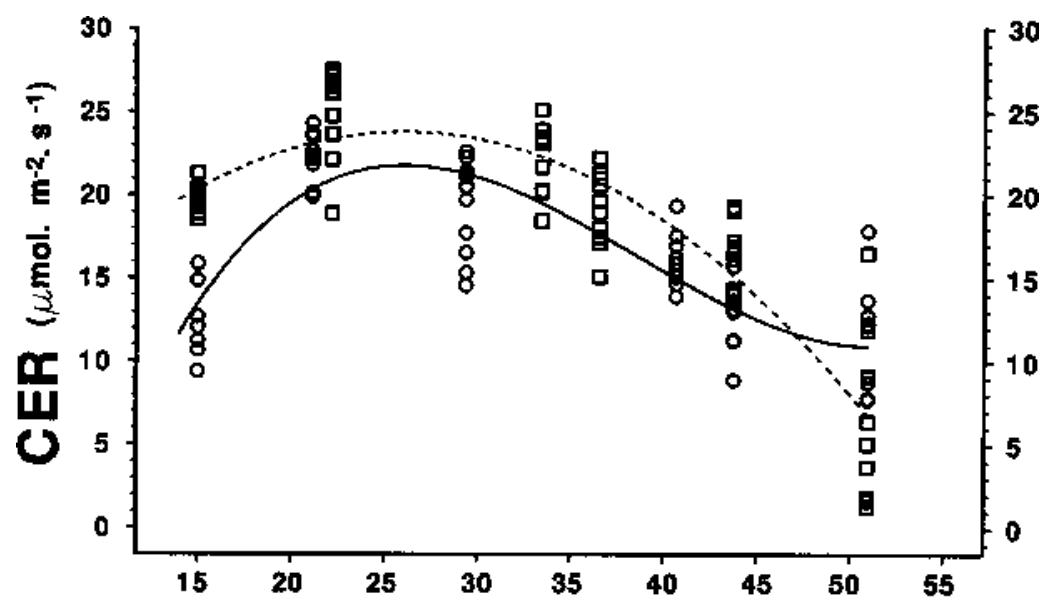

\section{DAYS FROM LEAF EMERGENCE}

Fig. 3. Effects of leaf age on $\mathrm{CO}_{2}$ exchange rate (CER) of okra. (-O- Expt. 1, y = 11.68 $+1.927 \mathrm{x}-$ $0.1084 \mathrm{x}^{2}+0.00151 \mathrm{x}^{3}, r^{2}=0.64^{* *} ;(---\square--)$ Expt. 2, y = 19.72+0.691x $-0.02918 \mathrm{x}^{2}, r^{2}=0.80^{* *}$. ${ }^{* *}$ Significant at $P \leq 0.01$.

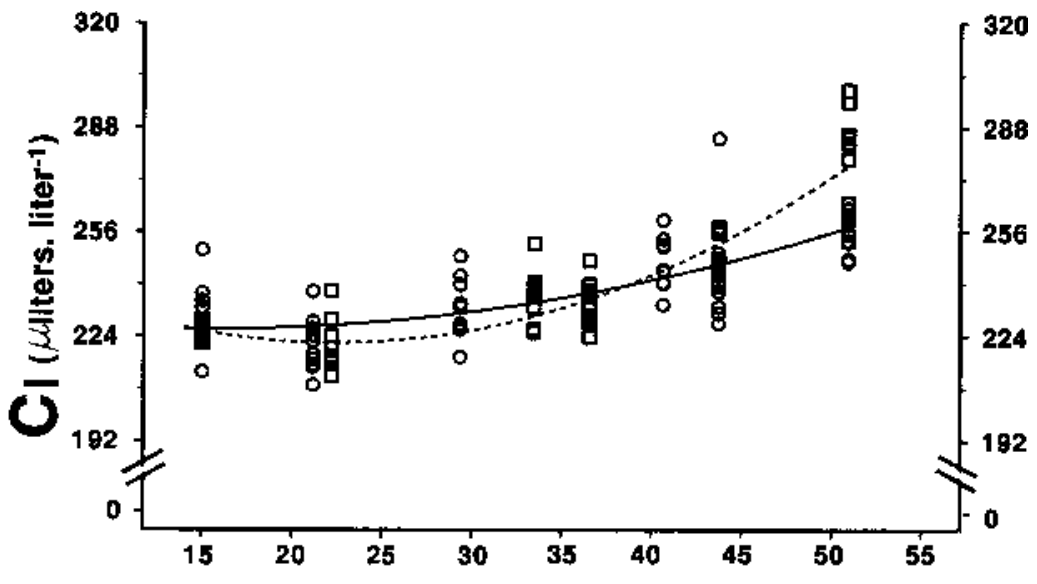

\section{DAYS FROM LEAF EMERGENCE}

Fig. 4. Effects of leaf age on internal leaf $\mathrm{CO}_{2}$ concentration $\left(\mathrm{C}_{\mathrm{i}}\right)$ of okra. (—O- Expt. $1, \mathrm{y}=226.2-0.068 \mathrm{x}$ $+0.02597 \mathrm{x}^{2}, r^{2}+0.54^{*} ;(-----)$ Expt. $2, \mathrm{y}=226.7-1.158 \mathrm{x}+0.07037 \mathrm{x}^{2}, r^{2}=0.81^{* *} .{ }^{*},{ }^{* *}$ Significant at $P \leq 0.5$ and 0.01 , respectively. 
ological characters in peas. Crop Sci. 22:773779.

Krieg, D.R. 1981. Leaf development and function as related to water stress. Proc. Beltwide Cotton Prod. Res. Conf. 1981. p. 41-42.

Osman, A.M. and F.L. Milthorpe. 1971. Photosynthesis of wheat leaves in relation to age, illuminance and nutrient supply. II. Results. Photosynthetica 5:61-70.

Pettigrew, W.T. and W.R. Meredith, Jr. 1994. Leaf gas exchange parameters vary among cotton genotypes. Crop Sci. 34:700-705.
Rasparuva, I.S. and B.R.H. Rasoluv. 1989. Influence of the unbalance source-sink relationship in the system of the whole plant on daily dynamics of carbon dioxide gas exchange components in cotton leaves (in Russian, English summary). Feiziologiya i Biokhimiya Kui' lurnykh Rastenii 2:107-112.

Singh, B.P. 1987. Effect of irrigation on the growth and yield of okra. HortScience 22:879-880.

Thakur, M.R. 1989. Okra, Abelmoschus esculentus (Linn.) Moench. Indian J. Hort. 33, 34:49-51.

Thompson, C.H. and C.W. Kelly. 1957. Veg- etable crops. McGraw-Hill, New York

Wullschleger, S.D. and D.M. Oosterhuis. 1989. Water use efficiency as a function of leaf age and position within the cotton canopy. Plant \& Soil 1:79-86.

Wullschleger, S.D. and D.M. Oosterhuis. 1990. Photosynthesis of individual field-grown cotton leaves during ontogeny. Photosynthesis Res. 23:163-170

Zelitch, I. 1982. The close relationship between net photosynthesis and crop yield. Bioscience 32:796-802. 